Status Report 2016-2019

\title{
Himalayan Cenozoic Biotas and Climate: An Overview of Recent Advances
}

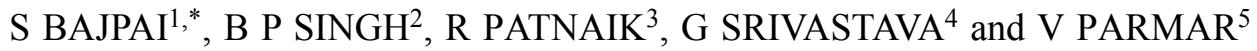 \\ ${ }^{1}$ Department of Earth Sciences, Indian Institute of Technology, Roorkee 247 667, India \\ ${ }^{2}$ Center of Advanced Study in Geology, Banaras Hindu University, Varanasi 221 005, India \\ ${ }^{3}$ Center of Advanced Study in Geology, Panjab University, Chandigarh 160 014, India \\ ${ }^{4}$ Birbal Sahni Institute of Palaeosciences, Lucknow 226 007, India \\ ${ }^{5}$ Post Graduate Department of Geology, University of Jammu, Jammu 180 006, India
}

(Received on 20 September 2019; Accepted on 29 September 2019)

\begin{abstract}
The early Cenozoic was a turning point in the geological history of the Indian subcontinent as it was during this interval that the Indian plate collided with Asia, leading to profound changes in global climates, faunal and floral evolution, orogeny and oceanography. Later Cenozoic records include those from the well known Siwalik successions which continue to yield important data relevant to age refinements of critical horizons including those yielding fossil hominoids, as well as for our understanding of the influence of climate change on the evolution of a diverse group of vertebrates including mammals. Studies on Himalayan Neogene floras have yielded phytogeographically important data as well as valuable insights in to paleotemperature and paleoprecipitation regimes. This report presents an overview of important recent contributions on the fossil fauna and flora, paleoenvironments and paleoclimates from the Himalayan Cenozoic sedimentary sequences.
\end{abstract}

Keywords: Himalaya; Cenozoic; Fossils; Paleoclimate

\section{Introduction}

The Paleogene evolution of the Himalayan foreland basin in the wake of initiation of India-Asia collision continues to be a much debated issue (Acharyya and Saha, 2018). As is well known, the continental collision between India and Asia is one of the most spectacular tectonic events of the Phanerozoic time and is crucial to our understanding of the global climate, mammal origins and dispersal, besides Himalayan-Tibetan orogeny (Chatterjee et al., 2017; Bajpai and Kapur, in press). Investigations carried out during the last four years (2016-2019) have led to a significant increase in our knowledge of the development of Himalayan Foreland Basin. The Siwalik strata of Neogene age in this foreland basin, extending from Arunachal Pradesh in NE India to the Potwar basin in NW Pakistan, have yielded one of the most impressive continental vertebrate records in the world. The Siwalik formations document differences in species richness, turnover, and ecological structure in

\footnotetext{
*Author for Correspondence: E-mail: sunil.bajpai@es.iitr.ac.in
}

a terrestrial setting, attributable to temporal changes in the fluvial systems, climate and vegetation change from a wet monsoonal forest to grassland during the Late Miocene. As the Himalaya continued to rise, precipitation not only would have increased, but seasonal changes would have become more sharply contrasted. The Siwalik vertebrates show an example of explosive evolution of the modern orders of mammals. Two major faunal turnovers, coinciding with global tectonic and climate changes, have been recognized in the Siwaliks during the Late Miocene (ca. $8 \mathrm{Ma}$ ) and the Late Pliocene (ca. 2.6 Ma). This article summarizes some of the major recent contributions on fossil fauna and flora, paleoenvironments and paleoclimates from the Himalayan Cenozoic sedimentary sequences.

\section{The Paleogene Interval}

During the past few years, significant advances have been made in our understanding of Himalayan foreland 
development, sedimentation as well as paleoenvironments. Acharyya and Saha (2018) argued that the Himalayan foreland basin formed over a failed rift zone that produced early Paleogene volcanism, as evident from the occurrence of rhyolitic chert breccia at the basal part of the foreland basin i.e. Subathu Formation in widespread sections. Based on mixed siliciclastic-carbonate microfacies, Bhatia et al. (2017) delineated the depositional sequences in the Subathu succession (Late Paleocene-Middle Eocene) exposed in the Bilaspur tectonic unit of the Sub-Himalaya. These authors distinguished a grainstone dominated unit of Ilerdian age representing a setting close to the platform edge, a mudstone dominated unit of Early-Late Cuisian age representing an open marine lagoon passing into a restricted inner platform setting and a thick peritidal carbonate sequence of Late Cuisian-arly Lutetian age, representing a deep, subtidal passing upwards to a supratidal setting. The facies architecture of the Subathu Formation encompasses transgressive, regressive and forced regressive phases of the shoreline migration history (Mishra et al., 2019).

In a study based on the carbonate distribution within the paleosol profiles of the Subathu-DagshaiKasauli sequence of the Himalayan foreland basin in Himachal Pradesh, it has recently been proposed that monsoonal circulation of modern strength appeared by at least $20 \mathrm{Ma}$ (Retalllack et al., 2017). The advent of monsoonal seasonality by $20 \mathrm{Ma}$ is close in time to radiometric and structural evidence for increased exhumation of the High Himalaya beginning, i.e. around $23 \mathrm{Ma}$. It should also be noted, however, that this study does not contradict an even older (Eocene) onset of monsoonal seasonality proposed by some previous workers on the basis of fossil wood, snails, and mammals in Myanmar or climate models suggesting monsoons as early as $45 \mathrm{Ma}$. In another study on Dagshai Formation of Himachal Pradesh dealing with morphological and micromorphological features of paleosols, Khanna et al. (2018) argued in favour of an early Oligocene initiation of monsoonal/ seasonal climate

The beginning of the Cenozoic in the Himalayan foreland well as other coeval basins in the Indian subcontinent was marked by the first major transgression in the late Paleocene ( $\sim 58 \mathrm{Ma})$. Based on sedimentological and paleontological data from the
Himalayan foreland basin as well as other coeval basins (Fig. 1), Singh et al. (2016) have interpreted that the primary driver for the late Paleocene transgression was the tectonics associated with the beginning of the India-Asia convergence. Singh et al. (2016) also identified a major regression of similar magnitude during the latest Middle Eocene (41.3-38.0 $\mathrm{Ma}$ ) that possibly corresponds to a global sea-level fall driven by global cooling during this interval associated with the nucleation of the Antarctica icesheets coupled with the uplift of the Himalaya.

The Paleogene succession of the Manipur region of northeastern Himalaya, represented by the Disang and Barail groups mainly exposed in the Imphal valley, has also attracted attention during the past few years. Based on biostratigraphic and sedimentological evidences, Singh et al. (2018) recently highlighted the Paleogene events of this region. The molluscan assemblage reported by these workers from the Upper Disang Formation of Changamdabi area of Imphal valley consists of 108 species ( 80 bivalve spp., 28 gastropod spp.). Based on this assemblage, three biostratigraphic zones, namely Zone-I ranging in age from Late Paleocene-Early Eocene (ThanetianYpresian), Zone-II ranging in age from Middle Eocene-Late Eocene (Lutetian-Bartonian) and ZoneIII of Late Eocene age (Priabonian), have been identified in ascending order of stratigraphy. These zones point to two major events in the Upper Disang Formation, i.e. shallowing of the sea-aerated water corresponding to Zones I and open sea conditions with well aerated warm water conditions corresponding to zones II and III. The occurrence of dinoflagellates (Eocene), flaser and lenticular bedding in the shale, siltstone and sandstone of the Upper Disang of Gelmoul quarry (Churachandpur) suggests a shallow marine (tidal flat) depositional environment. The overlying plant fossil- bearing Barail sequence (Oligocene) of Kaina Hills, Imphal valley indicates coastal/terrestrial environmental conditions under a warm and humid tropical climate.

\section{The Neogene Interval}

\section{Siwalik Vertebrates}

An almost continuous sequence of Siwalik freshwater deposits, $\sim 6000 \mathrm{~m}$ in thickness and ranging in age from $\sim 18 \mathrm{Ma}$ to $\sim 0.2 \mathrm{Ma}$, is exposed all along the Himalayan foothills extending from west to east. The 


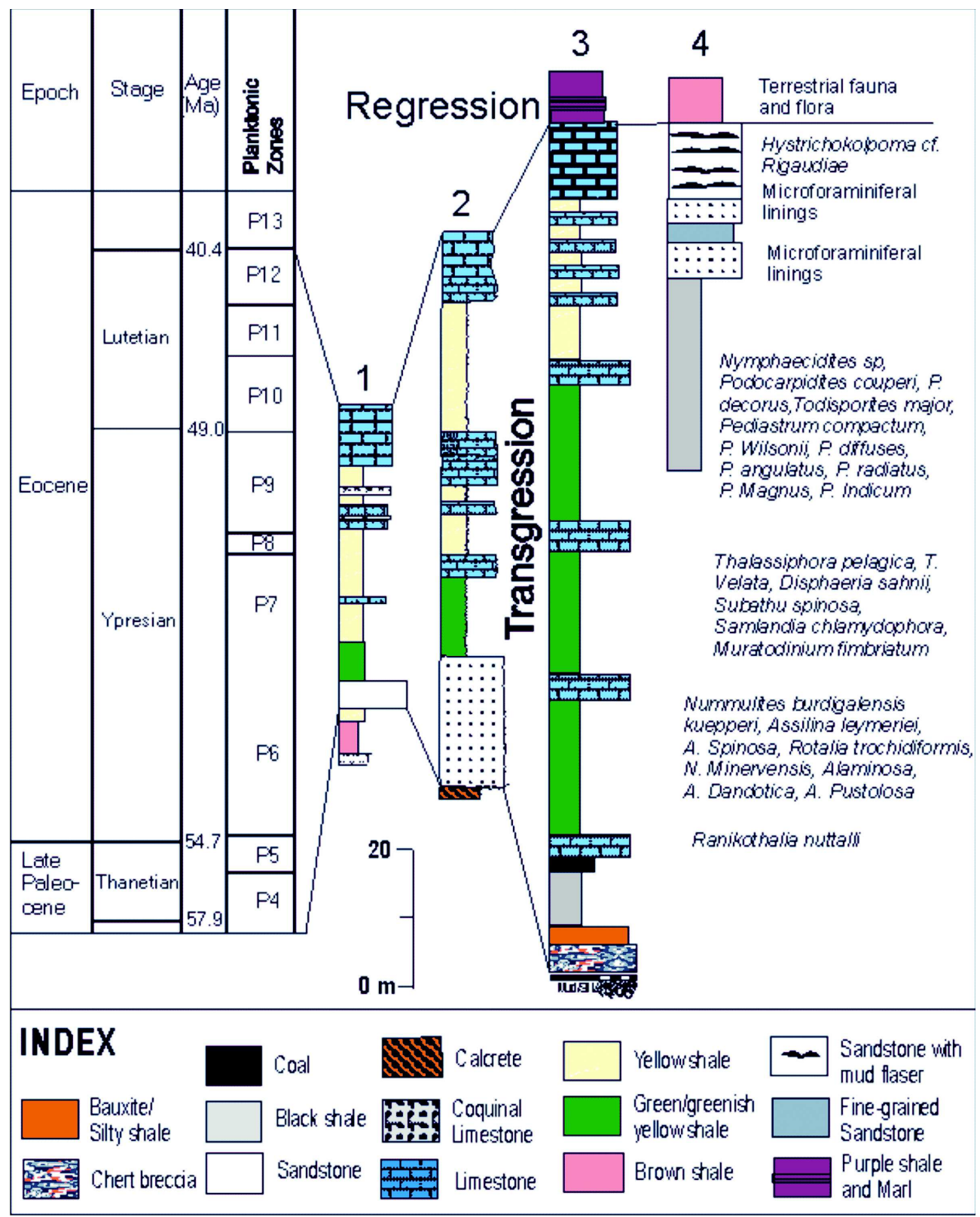

Fig. 1: Stratigraphic columns from the representative Paleogene sequences of India. 1 represents Kutch, 2 represents Jaisalmer, 3 represents Jammu and 4 represents Imphal valley, Manipur. Distribution of fauna and flora is given on extreme right

Siwalik successions of the Indian Himalaya continue to attract attention from palaeontological and sedimentological perspectives. Widely considered as excellent archives for Neogene and Quaternary fauna, these sediments have been known to yield fossils since the early $19^{\text {th }}$ century. Several key vertebrate- yielding localities are known south of the Main Boundary Thrust. Despite the fact that these classic localities are long known to yield fossil mammals, new discoveries are continuously being made ever since the bulk screen washing technique has been employed. Consequently, the Siwalik biostratigraphy is being updated regularly with new fossil discoveries made every now and then. Patnaik (2016) carried out a biostratigraphic evaluation of the Indian subcontinent Neogene-Quaternary mammalian biota including Siwalik taxa at a resolution of 1 my interval and suggested a strong correlation between faunal turnovers and sea-level and vegetational changes. More recently, Nanda et al. (2018) provided an 
updated review of the Siwalik biostratigraphy. Clearly, Siwaliks are still very relevant in the context of influence of climate change on the evolution of a diverse group of vertebrates including mammals. Emphasis has also been laid in recent years on other faunal elements from the Siwaliks.

During the past few years, Siwaliks have also been investigated from a sedimentological perspective. Shukla and Bora (2018) carried out lithofacies analysis of the Lower Siwalik subgroup of the Kumaun Himalaya, and described four depositional settings, namely, the Sandstone Lithofacies Association (Channel deposits), the Mudstone Lithofacies Association (Floodplain deposits), the Mottled Mudstone Lithofacies Association (Distal floodplain palaeosols), and the Mottled Siltstone Lithofacies Association (Interfluve deposits). The complete succession consists of two megacycles, one representing a prograding megafan deposit, and the other being characterised by river incision. In another study on facies characteristics and trace fossil assemblages from a $1.3 \mathrm{~km}$ thick succession of the Siwalik Group exposed in the Gish River section, Darjeeling foothills, Taral and Chakraborty (2016) concluded that, contrary to the existing alluvial fanbraided stream depositional model, this succession accumulated in a shallow marine deltaic setting, indicating the presence of a marine embayment in the Eastern Himalaya during the Siwalik time.

Some of the most important Siwalik sections are: Ramnagar Lower Siwalik and Jammu Upper Siwalik (Jammu Himalaya); Nurpur and Haritalyangar Middle Siwalik and Markanda valley Upper Siwalik (Himachal Himalaya); and Kalagarh Middle Siwalik (Uttarakhand Himalaya). New data on fossils from Lower, Middle and Upper Siwaliks in the last four years (2016-2019) are summarised below.

\section{Lower Siwaliks}

Hominoids and other mammals have been known from Lower Siwalik deposits exposed around Ramnagar (Jammu \& Kashmir) since the early twentieth century. Very recently, new primate fossils representing a new sivaladapid genus and species, Ramadapis sahnii was recovered from these sediments (Gilbert et al., 2017a). The specimen comprises a partial right mandible preserving the corpus with $\mathrm{P} 4$ roots and worn M1-M3 dentition (Fig. 2).
Another small-bodied ape has also been discovered from these layers increasing the Miocene ape diversity of the Siwaliks (Gilbert et al., 2017b). Ramnagar fossil-yielding sites were also subjected to taphonomic analyses using parameters such as number of vertebrate skeletal elements present, taxonomic diversity, degree of completeness, abrasion, breakage, weathering, and presence/absence of scavenging or carnivore marks (Singh et al., 2018). The results show that these fossils experienced short distance transportation and were accumulated by fluvial processes. Fossils also indicate presence of small streams, ponds/pools, swamps, and tropical rain forests developed under warm and humid conditions, with the possibility of more open environments closeby.

A small mammalian fauna comprising rodents including Megacricetodontinae represented by Punjabemys downsi and Punjabemys mikros, Rhizomyinae by Kanisamys indicus, Ctenodactylinae by Sayimys sivalensis, Myomiminae by Myomimus sp. and Xerinae by Tamiasurialis, has also been reported from the Lower Siwalik Subgroup exposed in the vicinity of Ramnagar town (Parmar et al., 2016, 2018). The cricetid rodents were reported from a locality about $10 \mathrm{~km}$ southeast of Ramnagar town near village Kalaunta (Parmar et al., 2016), whereas the other rodent taxa were documented from a fossiliferous horizon located about $8 \mathrm{~km}$ southwest of Ramnagar town near the village Dehari (Parmar et $a l ., 2018)$. These reports add significantly to the rodent diversity from this area and have important biochronological and palaeoecological implications. Parmar et al. (2016) provided an age estimate between $c a$. 13.9-13.0 Ma for a supposedly hominoidyielding site at Kalaunta, based upon rodent biochronology. This is a significant departure from the previous estimates of $c a .18 \mathrm{Ma}$ (Verma and Gupta, 1997). The fauna reported from Dehari by Parmar et al. (2018) included several taxa not described earlier from the Lower Siwalik of Jammu. In fact, prior to this work, the ctenodactylines, myomimines and xerines were not known to be present in India during the Lower Siwalik times. Parmar et al. (2018) estimated the age of the fossiliferous horizon at Dehari between 13.6-13.2 Ma and suggested a humid, forested Lower Siwalik landscape in Jammu Province during this time interval. Further, based on ecological adaptation of similar 

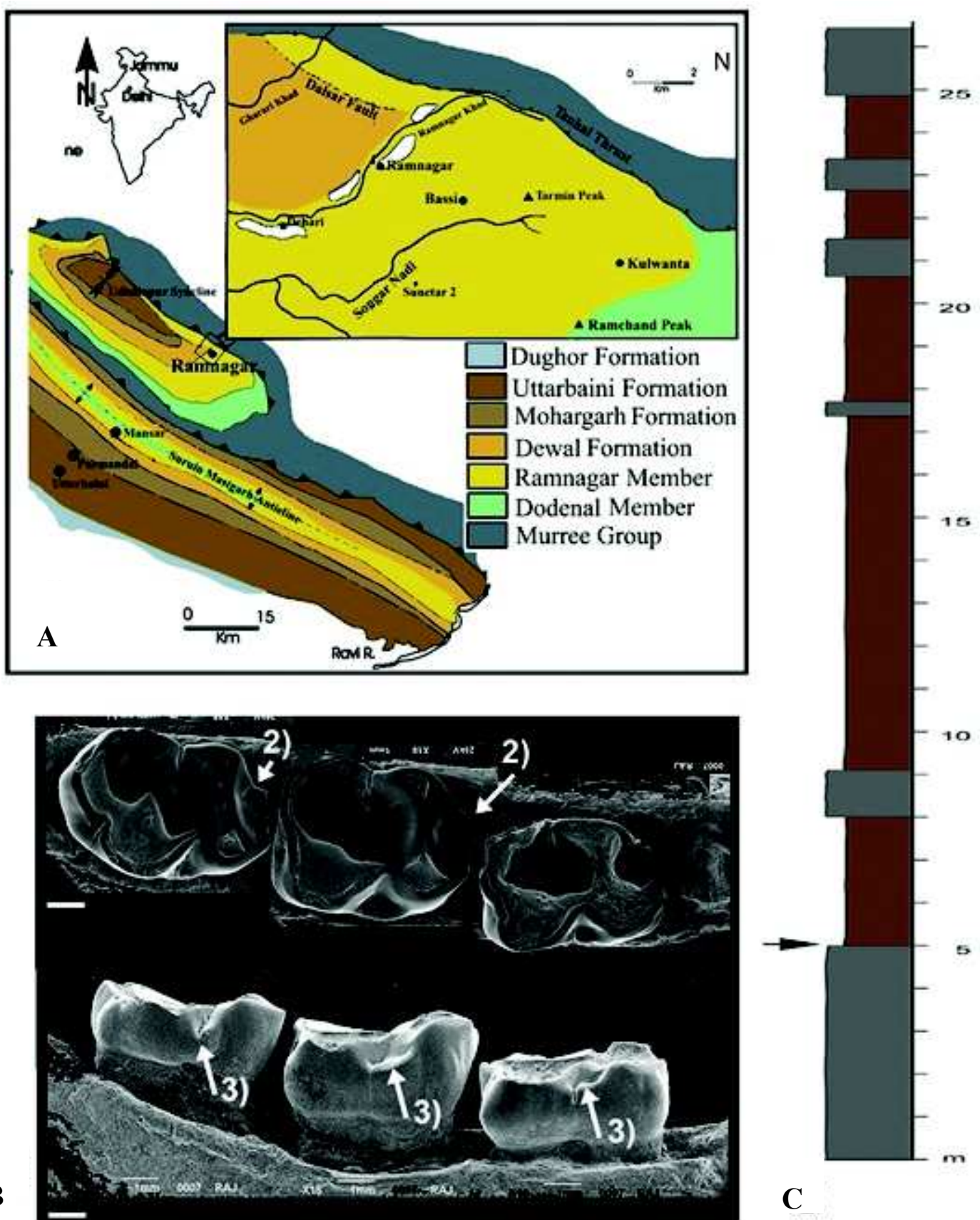

Fig. 2: A. General geological map of the Siwalik Group around Ramnagar with the primate-yielding locality Sunetar 2 (modified after, Thomas and Verma, 1979); B. Buccal and lingual views of the mandible of Ramadapis sahnii (VPL/RSP1) showing compressed trigonid (2) and weak buccal cingulid (3) (scale=1 mm) (after Gilbert et al., 2017a) and C. Simplified stratigraphic section at Sunetar 2. Black arrow indicates the primate- yielding level.

extant rodents, they suggested existence of a humid and forested palaeoecological setting for Dehari.

\section{Middle Siwaliks}

The Late Miocene Siwalik deposits exposed around Haritalyangar, Himachal Pradesh, are very well known for their fossil primates that inclues Sivapithecus, Sivaladapis and Indraloris. Recently, Sankhyan et al. (2017), recovered well preserved molars of a pliopethecoid Krishnapithecus krishnaii, which was earlier known by a highly worn molar. Sankhyan and Chavasseau (2018) also reported 
several dental remains of proboscideans such as Stegolophodon, ?Stegodon and Choerolophodon, besides specimens assignable to Gomphotheriidae or Amebelodontidae, most coming from the Upper Alternations of Haritalyangar area. Besides primates and proboscideans, Haritalyangar has also yielded a lizard chameleon (Sankhyan and Ėeròanský, 2016).

\section{Upper Siwaliks}

Upper Siwalik fossil bearing sites have received a lot of attention from both Indian and foreign experts in the last four years. Uppermost layers of Tatrot Formation yielded bovid bones with "intentional cut marks" (Malasse et al., 2016) and diverse faunal remains (Moigne et al., 2016). Kaur et al. (2019) reported porcupine (Hystrix) gnawing marks on a bone fragment most likely that of a mammal, dated to $\sim 2.6$ Ma from the Upper Siwalik deposits known from Khetpurali (Haryana). New dental remains of murid rodents Golunda kelleri, Mus flynni, Mus jacobsi and Abudhabia cf. A. kabulense were recovered from Devni Khadri belonging to Tatrot Formation. Based on the biostratigraphic ranges of these murid rodents from well dated Siwalik and Karewa localities, this richly fossiliferous locality has been placed here at $\sim 3 \mathrm{Ma}$. The new age facilitates regional correlation and a revision of stratigraphic placement of rodent bearing Plio-Pleistocene Indian sites. A cladistic analysis was carried out using fossil and extant Golunda and its relatives which supported a monophyly for the Golunda group. Kundal (2018) reported two specimens of fossil Mus from the mudstone horizon underlying $\sim 2.48$ Ma volcanic ash bed/bentonitized tuff near village Barakhetar (Jammu and Kashmir). He identified it as Mus cf. Mus flynni. From another site, Labli again below the volcanic ash layer, Kundal et al. (2017a) discovered one complete molar of a baby Stegodon, belonging to Stegodon cf. Stegodon insignis. Further, one specimen of Elephas cf. E. planifrons was described (Kundal et al., 2017b) from Nangal village, and the ash layer here is an extension of the layer at Barakhetar.

Siwaliks have so far yielded very few fossil birds. For the first time a darter (Anhingidae) from India was discovered by Stidham et al. (2017). The bird comes from $\sim 2.6 \mathrm{Ma}$ sediments of the Tatrot Formation. The darter fossils (Fig. 3 B-D) most likely represent a new species, but due to the limited information on the fossil record of this group their taxonomic allocation to a new species is not possible at the moment. The Pliocene darter specimens are the youngest of the very few Neogene records of the group from Asia. In addition, Nanda et al. (2016) reported new fossil reptiles; crocodiles Crocodylus aff. palustris, Gavialis cf. gangeticus, Rhamphosuchus crassidens, and turtles Batagur sp., Geoclemys hamiltoni and Hardella thurjii from the pre-Pinjor and Pinjor beds (Upper Siwalik Subgroup).

Recently, for the first time, Klaus et al. (2017) reported on a fossil freshwater crab from the Tatrot Formation in the Khetpurali section $(\sim 2.6 \mathrm{Ma})$ (Fig.3A). Based on characters of the preserved carapace and sternum the specimen was assigned to an extant species of the family Potamidae, subfamily Potaminae. The crab (Fig. 3F-H) is comparable to the extant species Acanthopotamon martensi that lives in the Ganges valley. The presence of a darter and pelican (along with crabs, fish, turtles, and crocodilians) in the same fossil-bearing horizon strongly indicates the past presence of a substantial water body (large pond, lake, or river) in the interior of northern India in the Himalayan foothills.

\section{Fossil Floras and Paleoclimates}

Since 2016, a considerable amount of work has been done on the qualitative as well as quantitative reconstruction of palaeoclimate by using plant fossils collected from the eastern, central and western part of the Himalaya (Adhikari et al. 2018; Khan et al. 2017; Srivastava et al., 2017, 2018 a, b). Studies on phytogeographic aspects have also been undertaken. In an important contribution, Morley (2018) recently discussed the issue of plant dispersal in to and out of India and South-East Asia in relation to plate tectonics and climate change. He suggested that India's drift into the perhumid low latitudes during the Eocene resulted in the dispersal of diverse groups of megathermal angiosperms into South-East Asia.

From the eastern Himalaya, Khan et al. (2017) reported fossil leaves, woods, and pollen grains belonging to the genus Calophyllum (family Calophyllaceae) from the middle and upper Siwalik sediments of the Arunachal Sub-Himalaya, and the lower Siwalik sediments of the Darjeeling foothills. These floral remains indicate a warm and humid tropical environment in the region during the period 

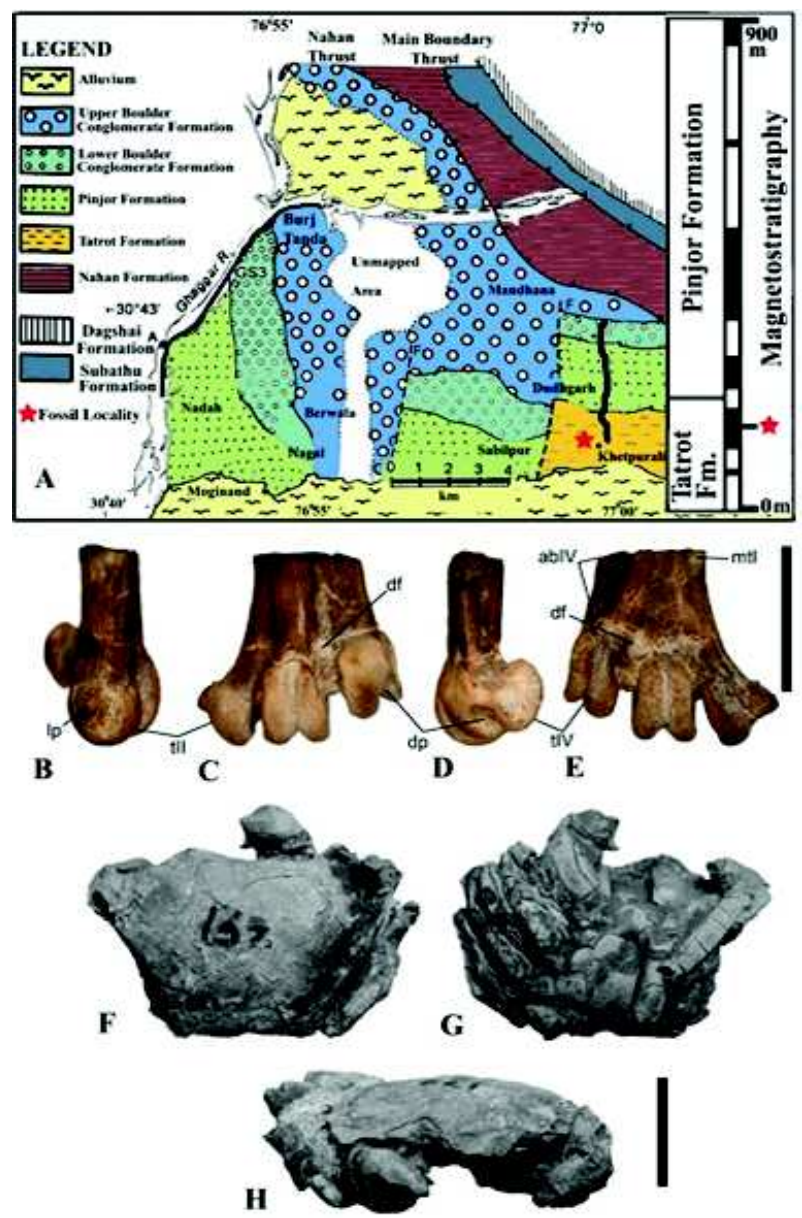

Fig. 3: A. The geology, location, stratigraphy, and magnetostratigraphy of the Ketpurali section and region, northern India. The vertebrate fossil bone horizon is marked with a red star. Fossil bird, distal tarsometatarsi. Anhinga sp. (VPL/RP-KPB1) from India in: (B) Medial view; (C) Dorsal View; (D) Lateral View. Scale bars equal $1 \mathrm{~cm}$. (modified after Stidham et al., 2017). Fossil crab Acanthopotamon martensi from the Tatrot Formation (KP/KK/BS/132). (F) Dorsal view; (G) sternal view and (H) frontal view. Scale bars $=1$ cm (modified after Klaus et al., 2016)

from Middle Miocene to early Pleistocene. The fossil data also suggests that India may have been the main centre of origin of Calophyllum. In another contribution, Khan et al. (2016) also reported the occurrence of Shorea fossils (impressions, compression, winged fruit, fruiting calyx lobes), in the lower, middle and upper Siwalik sediments of Arunachal Pradesh, eastern Himalaya. The discovery of Shorea, which is the largest and economically most important genus of the timber-producing family Dipterocarpaceae, indicates a tropical, warm and humid eastern Himalaya during the MiocenePleistocene time.

Paleobotanical investigations carried out by Srivastava et al. (2017, 2018 a, b) in the eastern Himalaya suggest that the Nearest Living Relatives (NLR) of plant fossils from the eastern and central Himalayan Siwaliks have important palaeoclimatic implications. The eastern Himalayan Siwalik taxa such as Calophyllum tomentosum and Mesua are now growing in areas with a less seasonal climate in terms of temperature and rainfall. Similar is the case for the genus Dipterocarpus reported from the central Himalayan Siwaliks. The modern distribution of the above genera suggests that seasonality in temperature and rainfall have increased due to the rising Himalaya since the middle Miocene. Quantitative reconstructions of palaeoclimate from the Bankas (Lower Siwalik) and Chor Khola (Middle Siwalik) formations of the Surai Khola section of the central Himalayan region have provided important insights. The reconstructed temperature Coexistence Intervals (CIs) obtained from the Bankas Formation flora are: $21.1-25.4^{\circ} \mathrm{C}$ (average $\sim 23.3^{\circ} \mathrm{C}$ ) for Mean Annual Temperature (MAT), 27.5$28.1^{\circ} \mathrm{C}$ (average $\sim 27.8^{\circ} \mathrm{C}$ ) for Temperature of the Warmest Month (WMT), 20.6-24.3 ${ }^{\circ} \mathrm{C}$ (average 22.4 ${ }^{\circ} \mathrm{C}$ ) for Temperature of the Coldest Month (CMT), and $\sim 5.4{ }^{\circ} \mathrm{C}$ (calculated using averages) for Mean Annual Range of Temperature (MART). The reconstructed CIs of the precipitation are: 1748-2869 $\mathrm{mm}$ (average $2308.5 \mathrm{~mm}$ ) for Mean Annual Precipitation (MAP), 300-329 mm for MPwet (average $\sim 314.5 \mathrm{~mm}$ ), $46-135 \mathrm{~mm}$ for MP dry (average $\sim 90.5 \mathrm{~mm}$ ), $128-221 \mathrm{~mm}$ for MPwarm (average $\sim 174.5$ ) and $\sim 224 \mathrm{~mm}$ (calculated using averages) for Mean Annual Range of Precipitation (MARP). The reconstructed temperature CIs obtained from the Chor Khola Formation flora are: $26-27{ }^{\circ} \mathrm{C}$ for MAT (average $\sim 26.5^{\circ} \mathrm{C}$ ), $26.7-27.8^{\circ} \mathrm{C}$ for WMT (average $\sim 27.3{ }^{\circ} \mathrm{C}$ ), $24.3-24.7^{\circ} \mathrm{C}$ for CMT (average $\sim 24.5^{\circ} \mathrm{C}$ ), and MART $\sim 2.8^{\circ} \mathrm{C}$ (calculated using averages). Precipitation reconstruction indicates CIs of 2592-3151 mm for MAP (average $\sim 2871.5$ $\mathrm{mm}$ ), 225-389 $\mathrm{mm}$ for MPwet (average $307 \mathrm{~mm}$ ), 8-59 $\mathrm{mm}$ for MPdry (average $\sim 33.5 \mathrm{~mm}$ ), 206-221 $\mathrm{mm}$ for MPwarm (average $\sim 213.5 \mathrm{~mm}$ ), and $\sim 273.5$ $\mathrm{mm}$ for MARP (calculated using averages).These quantitative reconstructions suggest that seasonality in rainfall has increased since the Middle Siwalik in the central Himalaya. The new quantitative data 
indicates that the increase in temperature and decrease in rainfall during the winter season in the Middle Siwalik probably enhanced the occurrence of forest fires with consequent expansion of $\mathrm{C}_{4}$ grasses.

The floristic assemblages also suggest that evergreen taxa were more dominant during the Lower Siwalik. However, the diversity of deciduous taxa increased significantly during the Middle Siwalik, suggesting that during the Lower Siwalik the rainfall pattern was more equable, whereas it became more seasonal in the Middle Siwalik.

Phytogeographically, the modern analogs of the plant fossils reported from the eastern and central Himalayan Siwaliks are of great interest because many of these taxa do not presently exist in the vicinity of the region. The eastern Himalaya Siwalik taxa such as Calophyllum tomentosum is now endemic to the wet evergreen forests of Western Ghats, while Mesua (Kayea) is restricted to evergreen forests of south and southeast Asia. Moreover, Sindora siamensis is presently confined to southeast Asia and Dipterocarpus is now growing in northeast India and Western Ghats but not in the vicinity of the fossil locality.

In another work (Srivastava et al., 2018c), fossil wood of Lagerstroemia of the family Lythraceae reported from the Hagnus member of Karit Formation (latest Miocene) of Sumdo village, Kargil, Jammu \& Kashmir, suggests that the fossil locality was warmer

\section{References}

Acharyya S K and Saha P (2018) Himalayan Paleogene Foreland Basin, its collision induced early volcanic history and failed rift initiation. Journal of Asian Earth Sciences 162 3-12

Adhikari P, Srivastava G, Mehrotra R C, Adhikari D, Shrestha K, Uhl D and Paudayal K N (2018) Leaf impressions of Terminalia (Combretaceae) and Daphnogene (Lauraceae) from the Middle Siwalik of the Chatar-Barahakshetra area, eastern Nepal Bulletin Department of Geology, Tribhuvan University, Kathmandu, Nepal 20-21 21-28

Bajpai S and Kapur V (2019, in press) India's geodynamic evolution during the Eocene: perspectives on the origin and early evolution of modern mammal orders. Legacy Volume Episodes and the area was at a low elevation in contrast to the modern-day elevation of $\sim 3559 \mathrm{~m}$. Furthermore, this find is phytogeographically significant since Lagerstroemia does not grow in the vicinity of the fossil locality, suggesting a drastic climate change since the late Miocene.

\section{Concluding Remarks}

Summing up, significant advances have been made during the past four years to understand the development and sedimentation patterns and biostratigraphic age refinements of the Himalayan foreland basin, particularly from the Eocene (Subathu Formation and correlatives) and Neogene (Siwalik) deposits of the Himalaya. In addition, remarkable improvements have been made towards quantitative assessment of Neogene paleoclimates using fossil floras and their Nearest Living Relatives (NLR). Sustained efforts in this direction are needed. Efforts also need to be made to fill the existing gaps in the vertebrate record, particularly from the Paleocene, as this will likely open up many new questions and will have an important bearing on our understanding of the origin, evolution and dispersal of the various groups of vertebrates.

\section{Acknowledgements}

R P acknowledges support from Ministry of Earth Science (MoES/P.O. (Geoscience)/46/2015) and SERB (HRR/2018/000063), New Delhi.

Bhatia S B, Bhargava O N, Bagi H and Singh B P (2017) Carbonate microfacies from a Paleocene-Eocene succession of an attached platform - a case study from the Sub- Himalaya Journal of the Palaeontological Society of India 62 1-16

Chatterjee S, Scotese C and Bajpai S (2017) The restless Indian plate and its epic voyage from Gondwana to Asia: its tectonic, paleoclimatic and paleobiogeographic evolution. Special paper Geological Society of America 529 1-147

Gilbert C C, Patel B A, Singh N P, Campisano C J, Fleagle J G, Rust K L and Patnaik R (2017a) New sivaladapid primate from Lower Siwalik deposits surrounding Ramnagar, Jammu and Kashmir state, India Journal of Human Evolution 10 221-41

Gilbert C C, Patel B A, Singh N P, Campisano C J, Fleagle J G, Rust K L, Pugh K D and Patnaik R (2017b) New fossil 
primates from the Lower Siwaliks of India. American Journal of Physical Anthropology Suppl 64

Kaur J, Patnaik R, Singh B and Krishan K (2019) Porcupine gnaw marks on a Late Pliocene bone from the Upper Siwaliks exposed near Village Khetpurali (Haryana, India) (2019) An Acad Bras Ciênc [online]. vol.91, n.1, e20170910. Epub Feb 14, 2019. ISSN 0001-376

Khan MA, Spicer RA, Spicer T E V and Bera S (2017) Occurrence of Shorea Roxburgh ex C. F. Gaertner (Dipterocarpaceae) in the Neogene Siwalik forests of eastern Himalaya and its biogeography during the Cenozoic of Southeast Asia Review of Palaeobotany and Palynology 233 236-254

Khan M A, Spicer R A, Spicer T E V and Bera S (2017) Evidence for diversification of Calophyllum L. (Calophyllaceae) in the Neogene Siwalik forests of eastern Himalaya Plant Systematics and Evolution 303 371-386

Khanna Y, Singh S and Singh S (2018) Micromorphological studies of the complex early Oligocene Himalayan foreland palaeosols in relation to Asian monsoon climate Catena $1641-12$

Klaus, S, Singh B, Hartmann L, Krishan K, Ghosh A and Patnaik $\mathrm{R}$ (2017) A fossil freshwater crab from the Pliocene Tatrot Formation (Siwalik Group) in Northern India (Crustacea, Brachyura, Potamidae) Palaeoworld 26 566-571

Kundal S N (2018) Mus cf. Mus flynni (Rodentia, Mammalia) from mudstone horizon underlyiong ASH BEDS, Upper Siwalik of Samba district, Jammu and Kashmir, India Arabian Journal of Geosciences 11474

Kundal S N, Bhadur G and Kumar S (2017a) A Late Pliocene baby Stegodon cf.Stegodon insignis (Proboscidea) from Upper Siwalik of Samba District, Jammu and Kashmir India Earth Science India 10 82-93

Kundal S N, Bhadur G and Kumar S (2017b) Elephas cf. E. planifrons (Elephantidae, Mammalia) from Upper Siwalik Subgroup of Samba district, Jammu and Kashmir, India. Vertebrata Pal Asiatica 55 59-70

Malassé AD, Moigne A M, Singh M, Calligaro T, Karir B, Gaillard C, Kaur A, Bhardwaj V, Pal S, Abdessadok S, Chapon S, Cécile G, Julien T, Alina S and Miguel G (2016) Intentional cut marks on bovid from the Quranwala zone, 2.6 Ma, Siwalik Frontal Range, northwestern India C R Palevol 15 317-339

Mishra S R, Karmakar R, Tripathi S C, Gupta M and Sarswat R (2019) Facies architecture and depositional evolution of Palaeocene-Eocene, Subathu Formation, Garhwal Himalaya, Uttarakhand, India Journal of Earth System Science $\mathbf{1 2 8} 82$

Moigne A-M, Dambricourt M A, Singh M, Bhardwaj V, Gaillard
C, Kaur S, Karir B, Pal S, Abdessadok S, Chapon Sao C, Gargani J and Tudryn A (2016) The faunal assemblage of the paleonto-archeologicallocalities of Masol Formation, Late Pliocene Quranwala Zone, NW India. In: Human origins on the Indian sub-continent $C R$ Palevol 15359 378

Morley R (2018) Assembly and division of the South and SouthEast Asian flora in relation to tectonics and climate change Journal of Tropical Ecology 34 209-23

Nanda A C, Schleich H and Kotlia B (2016) New Fossil Reptile Records from the Siwalik of North India Open Journal of Geology 06 673-691

Nanda A C, Sehgal R K and Chauhan P R (2018) Siwalik-age faunas from the Himalayan Foreland Basin of South Asia Journal of Asian Earth Sciences 162 54-68

Parmar V, Magotra R, Norboo R and Prasad G V R (2016) Rodentbased age appraisal of the Lower Siwalik Subgroup of Kalaunta, Ramnagar, Jammu, India Alcheringa 42 124133

Parmar V, Prasad G V R and Norboo R (2018) Middle Miocene small mammals from the Siwalik Group of Northwestern India Journal of Asian Earth Sciences 162 84-92

Patnaik R, Kotla S S, Singh N P, Singla A and Kaur J (2017) A new murid rodent assemblage from the Upper Siwaliks, Himachal Pradesh, India:Biostratigraphic, Phylogenetic and Palaeobiogeographic implications Journal of Asian Earth Sciences 162 93-106

Patnaik R (2016) Neogene-Quaternary Mammalian Paleobiogeography of the Indian Subcontinent: An appraisal Comptes Rendus Palevol http://dx.doi.org/10.1016/ j.crpv.2015.11.004

Retallack G J, Bajpai S, Liu X, Kapur V V and Pandey S K (2018) Advent of strong South Asian monsoon by 20 million years ago Journal of Geology 126 1-24

Sankhyan A R and Èeròanský A (2016) A first possible chameleon from the Late Miocene of India (the hominoid site of Haritalyangar): A tentative evidence for an Asian dispersal of chameleons The Science of Nature 10394

Sankhyan A R, Kelley J and Harrison T (2017) A highly derived pliopithecoid from the Late Miocene of Haritalyangar, India Journal of Human Evolution 105 1-12

Sankhyan AR and Chavasseu O (2018) New proboscidean fossils from Middle Siwaliks of Haritalyangar, Himachal Pradesh, India Palaeontologica Electronica https://doi.org/10.26879/ 844

Shukla U K and Bora D S (2019) The Lower Siwalik foreland basin sedimentation in the Kumaun Himalaya (India): A transition from megafan setting to incised valley fills 
Journal of Geodynamics 129 219-236

Singh B P, Singh Y R, Andotra D S, Patra A, Srivastava V K, Guruaribam V, Sijagurumayum U and Singh G P (2016) Tectonically driven late Paleocene (57.9-54.7 Ma)

transgression and climatically forced latest middle Eocene (41.3$38.0 \mathrm{Ma}$ ) regression on the Indian subcontinent Journal of Asian Earth Sciences 115 124-132

Singh N P, Gilbert C C, Patel B A and Patnaik R (2018) The taphonomy and palaeoecology of the Middle Miocene hominoid locality of Ramnagar (Jammuand Kashmir, India) Journal of Asian Earth Sciences 162 93-106

Singh Y R, Sijagurumayum U and Singh B P (2018) Molluscan biostratigraphy and palynological assemblage of Paleogene Disang Formation, Manipur, India The Indian Paleogene (Eds., S. Bajpai, S. C. Tripathi, V. Prasad) pp. 309-327

Srivastava G, Adhikari P, Mehrotra R C, Paudel L, Uhl D and Paudayal K N (2017) Dipterocarpus Gaertn. (Dipterocarpaceae) leaf from the Middle Siwalik of eastern Nepal and its phytogeographic and climatic significance Journal of the Nepal Geological Society 53 39-46

Srivastava G, Mehrotra R C and Srikarni C (2018a) Fossil wood flora from the Siwalik Group of Arunachal Pradesh, India and its climatic and phytogeographic significance Journal of Earth Systems Science $\mathbf{1 7 6} 6$

Srivastava G, Mehrotra R C and Srikarni C (2018b) Lagerstroemia L. wood from the Kimin Formation (Upper Siwalik) of Arunachal Pradesh and its climatic and phytogeographic significance Journal of the Geological Society of India 91 695-699

Srivastava G, Mishra S R, Barman P, Mehrotra R C and Tripathi S C (2018c) Lagerstroemia L. fossil wood from the Indus molasse sediments (possibly late Miocene) of TransHimalayan region and its phytogeographic and climatic significance Review of Palaeobotany and Palynology 255 14-21

Stidham T, Patnaik R, Krishan K, Singh B, Ghosh A, Singla A, et al. (2017) The first darter (Aves: Anhingidae) fossils from India (late Pliocene) PLoS ONE 12 e0177129 https:// doi.org/10.1371/journal.pone.0177129

Taral S and Chakraborty T (2018) Deltaic coastline of the Siwalik (Neogene) foreland basin: evidences from the Gish River section, Darjeeling Himalaya Geological Journal 53 203229

Verma B C and Gupta S S (1997) New light on the antiquity of Siwalik great apes Current Science 72 302-303. 